\title{
Heavy metal burden of predatory birds in Eastern Hungary
}

\author{
Adrienn GRÚZZ ${ }^{1}$ - Rita SZABÓ ${ }^{1}$ - János DÉRI ${ }^{2}$ - Péter BUDAI ${ }^{1}$ - József LEHEL ${ }^{3}$ \\ 1: Institute for Plant Protection, Georgikon Faculty, University of Pannonia, Deák F. u. 16., Keszthely H-8360, \\ Hungary; E-mail: gruz.adri@gmail.com, szabo-r@georgikon.hu, budai-p@georgikon.hu \\ 2: Bird Hospital Foundation, Petőfi tér 6. Hortobágy, H-4071, Hungary; E-mail: madarkorhaz@gmail.com \\ 3: Department of Food Hygiene, University of Veterinary Medicine, István u. 2. Budapest H-1400, Hungary; \\ E-mail: Lehel.Jozsef@univet.hu
}

Keywords: environmental contaminants, heavy metals, predatory birds, feathers, pollution monitoring

\section{Introduction}

In recent years heavy metals have become a great concern for human, animal and environmental welfare due to the pollution arising from increased anthropogenic activities, such as industrial and agricultural use (crop protection, fertilizers, steel manufacturing, mining, wastewater sludge, drugs and dyes additives, improperly coated food containers etc.). Among the heavy metals, lead ( $\mathrm{Pb})$, mercury $(\mathrm{Hg})$, arsenic (As) and cadmium $(\mathrm{Cd})$ are the most commonly associated with poisoning of both human and animal. Many of them are persistent and can accumulate in the body of living organisms, e.g. in kidney, liver, blood, feathers, eggs and bones of the birds (Burger and Gochfeld, 1993; Mateo and Guitart, 2003; Jayakumar and Muralidharan, 2011). Due to the accumulation property of heavy metals in wild birds' tissues, they can be used as bio-indicators for environmental contamination. Using feathers is a non-invasive way to collect tissue samples from birds, which can provide a useful and non-destructive tissue e.g. for mercury analysis because birds excrete substantial level of metals in the feathers, where their rate is nearly constant for mercury, and relatively high for other metals (Burger and Gochfeld, 2000).

\section{Materials and methods}

The feather samples were collected in the Hortobágyi Madárpark (Bird Hospital Foundation) and the birds were originated from the eastern region of Hungary. The following data were noted during the samplings: time and location of finding, gender and birds' age. Samples were collected from 123 predatory birds including: Owls - Longeared owl (Asio otus), Barn owl (Tyto alba), Tawny owl (Strix aluco), Little owls (Athene noctua), Buzzards (Buteo buteo), Common kestrels (Falco tinnunculus) and Eurasian sparrow-hawks (Accipiter nisus). To determine the concentration of $\mathrm{Pb}, \mathrm{As}, \mathrm{Cd}$ and $\mathrm{Hg}$ inductively coupled plasma optical emission spectrometry was used.

Differences between the genders and ages were calculated by Wilcoxon rank-sum test. The correlation among heavy metals ( $\mathrm{P}$-value $<0.05$ was significant) was analysed by Spearman rank-correlation test. The statistical analysis of the data was performed using the Software: $\mathrm{R}$ version 3.4.2.

\section{Results and discussion}

Values of As were ranged from $0.29 \pm 0.24$ to $0.40 \pm 0.30 \mathrm{mg} / \mathrm{kg}$. As concentration in four species of Strigidae family was $1.06-6.44 \mathrm{mg} / \mathrm{kg}$, and in the USA the concentration of 5 $\mathrm{mg} / \mathrm{kg}$ was measured in a possible As contaminated area (Nighat et al., 2013; Wiemeyer et al., 1980). The average of Cd concentrations was from $0.09 \pm 0.03$ to $0.20 \pm 0.18 \mathrm{mg}$ / 
$\mathrm{kg}$, which is much lower than the accepted threshold value for Cadmium in birds ( $3 \mathrm{mg}$ / $\mathrm{kg}$ according to Nighat et al., 2013). However, adverse effects can be realised due to level of $0.1-2 \mathrm{mg} / \mathrm{kg}$, in other aspect (Burger, 1993). Pb concentrations were averaged from $1.15 \pm 1.40$ to $2.30 \pm 1.52 \mathrm{mg} / \mathrm{kg}$ that were lower than the level causing adverse effect $(4 \mathrm{mg} /$ $\mathrm{kg}$ ) measured by Burger and Gochfield (2000). The threshold for toxicity of $\mathrm{Hg}$ in bird species is highly variable amongst difference species. Sublethal levels started from $2.4 \mathrm{mg} /$ $\mathrm{kg}$ can cause impairments in the reproductive processes (Scheuhammer et al., 2007). In our research, $\mathrm{Hg}$ concentrations averaged from $0.58 \pm 0.31$ to $2.19 \pm 1.25 \mathrm{mg} / \mathrm{kg}$. There were no significant differences in concentration of heavy metals between genders or age of species. There was medium significant correlation between $\mathrm{Cd}$ and $\mathrm{As}(0.43)$, and $\mathrm{Pb}(0.38)$ in Owls, between $\mathrm{Cd}$ and $\mathrm{Pb}$ in Buzzards (0.51) and in Eurasian sparrow-hawks (0.49) but it was not realised in Common kestrels based on the Spearman rank-correlation test.

\section{Conclusions}

Feather examination for detecting heavy metal burden is a worldwide known and is frequently used biomonitoring tool due to a strong correlation between the heavy metal concentration of feathers and the near environment of the birds. Even though our work did not show correlation between the ages and the sexes, it can be stated, based on our data and other similar studies, that the concentration of these heavy metals mostly stays below the level what can cause adverse or toxicological effects in birds.

\section{Acknowledgement}

The Project was supported by the European Union and co-financed by the European Social Fund (grant agreement no. EFOP-3.6.3-VEKOP-16-2017-00005 and EFOP-3.6.2-162017-00012).

\section{References}

Burger, J., Gochfeld, M. (1993): Heavy metal and selenium levels in feathers of young egrets and herons from Hong Kong and Szechuan, China. Archives of Environmental Contamination and Toxicology. 25:322-327. https://doi.org/10.1007/bf00210724

Burger, J., Gochfeld, M. (2000): Metals in albatross feathers from Midway Atoll: influence of species, age, and nest location. Environmental Research. 82:207-221. https://doi.org/10.1006/enrs.1999.4015

Jayakumar, R., Muralidharan, S. (2011): Metal Contamination in Select Species of Birds in Nilgiris District, Tamil Nadu, India. The Bulletin of Environmental Contamination and Toxicology. 87:166-170. https://doi. org/10.1007/s00128-011-0323-y

Mateo, R., Guitart, R. (2003): Heavy metals in livers of water birds from Spain. Archives of Environmental Contamination and Toxicology. 44:398-404. https://doi.org/10.1007/s00244-002-2040-3

Nighat, S., Aqbal, S., Nadeem, M. S., Mahmod, T., Shah, S. I. (2013): Estimation of heavy metal residues from the feathers of Falconidae, Accipitridae, and Strigidae in Punjab, Pakistan. Turkish Journal of Zoology. 37:488-500. https://doi.org/10.3906/zoo-1112-1

Scheuhammer, A. M., Meyer, M. W., Sandheinrich, M. B., Murray, M. W. (2007): Effects of environmental methylmercury on the health of wild birds, mammals, and fish. Ambio, 36:12-18. https://doi.org/10.1579/00447447(2007)36[12:eoemot]2.0.co;2

Wiemeyer, S., Lamont, T., Locke, L. (1980): Residues of Environmental Pollutants and Necropsy Data for Eastern United States Ospreys, 1964-1973. Estuaries, 3:155-167. https://doi.org/10.2307/1352065 